\begin{tabular}{|c|c|}
\hline $\begin{array}{c}\text { European Association for the } \\
\text { Development of Renewable Energies, Environment } \\
\text { and Power Quality (EA4EPQ) }\end{array}$ & $\begin{array}{c}\text { International Conference on Renewable Energies and Power Quality } \\
\text { (ICREPQ'12) }\end{array}$ \\
Santiago de Compostela (Spain), 28th to 30th March, 2012
\end{tabular}

\title{
Comparative study of the opportunity to use Renewable Energy Sources to supply Residential Consumers
}

\author{
F. D. Surianu ${ }^{1}$, I. Borlea ${ }^{1}$, D. Jigoria-Oprea ${ }^{1}$ and B. Lustrea ${ }^{1}$ \\ ${ }^{1}$ Department of Power Engineering \\ "Politehnica" University of Timisoara \\ V. Parvan 2, 300223, Timisoara, Romania \\ Phone/Fax number:+40 256 403413, e-mail: flavius.surianu@et.upt.ro, dan.jigoria@et.upt.ro
}

\begin{abstract}
Taking into account the directions of the European Union, concerning the increasing role of renewable power sources for supplying loads and reduction of $\mathrm{CO}_{2}$ emission, this paper presents details of the technical and economic characteristics of the main types of renewable power sources. It also analyzes the feasible technologies to ensure the supply of power to the residential areas using different renewable power sources. Using HOMER, the program meant for the optimal choice of power sources that supply electric loads, the paper has made a comparative technical and economic analysis of the supplying possibilities of a micro power system, using renewable power sources: wind, biogas, PEM fuel-cells and photovoltaic panels.
\end{abstract}

\section{Key words}

renewable energy, wind turbine, photovoltaic cell, biomass, fuel cell

\section{Introduction}

Nowadays, the mankind is living an energy crisis. The most optimist forecasts reveal the fact that the main classic energy resources (oil and natural gas) will be exhausted until 2050. Also, the combustion causes the greenhouse effect which will determine an apocalyptical scenario in the next (80-100) years.

In this scenario, the only solution is finding and using new energy resources, inexhaustible and clean, which will substitute in the next 50 years the current resources based on fossil fuels.

The growing share of renewable energy production is predictable but depends both on reducing the production costs and on finding new electrical energy storage solutions. This will ensure the injection into the power system of large quantities of renewable energy. Even more, the legislation regarding environment protection imposes the usage of this kind of energy. In March 2007, a European agreement was signed, which impose the reduction of $\mathrm{CO}_{2}$ emission with $20 \%$ until 2020 and 50\% until 2050, but also using the biofuels with a share of $10 \%$ [2].

\section{Renewable energy used for residential consumers}

Wind energy is used by the wind turbines, which nowadays have rated powers up to $3 \mathrm{MW}$. The investments in this area are growing day by day, wind energy being used by consumers in rural and extra-urban areas with important wind potential. In Romania, important wind farms are in Banat and Dobrogea and the production of wind energy increased four times since 2006.

Hydropower is efficient used in conventional hydropower plants. An important component in using efficient the water energy are the small run-on-the-river hydro-plants with powers up to several hundreds of $\mathrm{kW}$, used to supply residential consumers. An attractive, technological and economical feasible solution, but with large investments, are pumped-storage facilities. Romania's hydropower potential is 32,000 GWh/year, with 5,000 GWh/year for small hydro power, with only 55\% used at this time.

Solar power is a natural, ecological and inexhaustible energy source used mainly for supplying the residential consumers. The share of solar energy in renewable energy sources in Romania in 2010 was $8 \%$.

Biomass is an organic resource used to generate energy and is composed by biodegradable agricultural waste, wood and a fraction of industrial waste. By using biomass in Romania, one fifth of the primary resource consumption could be supplied and also $90 \%$ of the energy needed for heating in rural areas.

Geothermal power is used in geothermal heat pumps and geothermal heating systems. Although the construction of a geothermal power plant is expensive, the low maintenance costs determine a small energy price. The geothermal reserve in Romania is about $167 \times 103$ toe and 70 hot water pumps are in use, while 45 are in conservation or reserve.

Because it not exists free in nature, hydrogen does not represent a renewable source of energy. To generate, transport and store hydrogen, energy is needed. Due to the development of technology in the past years, it can be said that the mankind is on the way to hydrogen savings. This 
is because hydrogen can be used in fuel cells, generating electrical energy and hot water, or in hydrogen engines, where it generates mechanical energy and water. So, it is safe to say that the combustion of hydrogen is a non pollutant process [3]-[10].

\section{Description of HOMER software - an optimal analysis tool}

Homer (Hybrid Optimization Model for Electric Renewables) was developed by NREL (National Renewable Energy Laboratory, Colorado USA), as a work platform for optimal selection of independent, interconnected or distributed power sources for consumers, connected or not connected to the public grid [1].

The processed information by HOMER refers to:

- power sources: photovoltaic panels, wind turbines, small hydropower plants, diesel generators, biomass, biogas, fuel cells, public grid;

- energy storage: hydrogen, batteries;

- consumers: daily and annual load curves, water pumping, heating, ventilation and air conditioning, energy conservation.

Using HOMER involves the following steps:

- in the initial phase, all the technical possible combinations for supplying the consumers using the specified power sources are determined. Next, the energy balance for $8760 \mathrm{~h} /$ year and all the possible alternatives to provide the energy are determined;

- in the second phase, for every alternative a full economical estimation (considering all the expensed regarding the initial investments, maintenance, repairing, modernization, interests and benefits) is computed.

- the third phase optimizes economically the proposed solutions and presents them in ascending order of costs per life cycle;

- In the fourth phase, sensitivity indexes of the results considering the variations of the input data are computed.

Finally, from the presented results, the user can decide which the best solution to supply the consumers is.

\section{Case study using HOMER}

\section{A. Test system description}

For the case study, a medium size extra-urban residential area with 60 houses is considered. Each house accommodates 3-4 persons and has an installed electrical power of $5 \mathrm{~kW}$ and a $15 \mathrm{~kW}$ thermal load. For all the considered area, the electric load is $300 \mathrm{~kW}$ and the maximum thermal load is $600 \mathrm{~kW}$.

Figure 1 presents the estimated electrical and thermal daily load curve for a day in January.

Estimated monthly electrical and thermal loads are represented in Fig. 2 and Fig. 3.

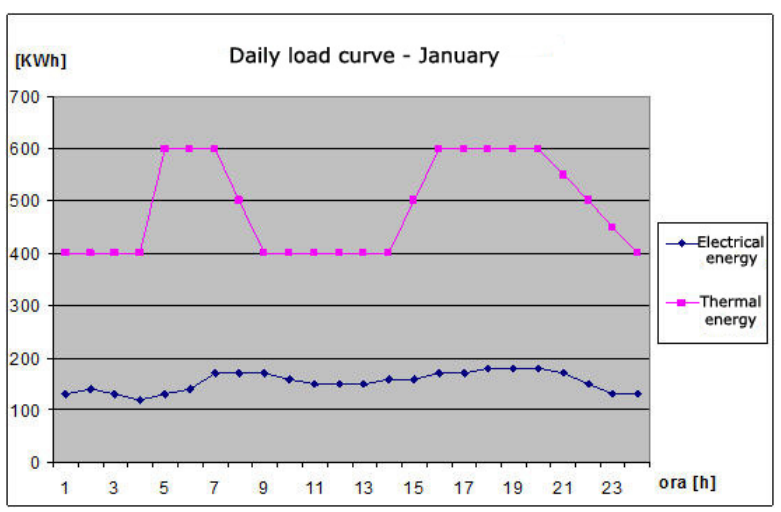

Fig. 1. Daily electrical and thermal load curves for January

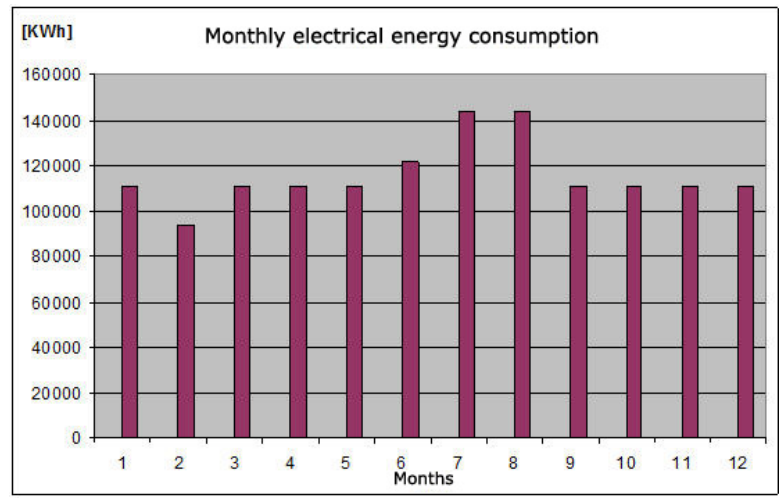

Fig. 2. Estimated monthly electrical load

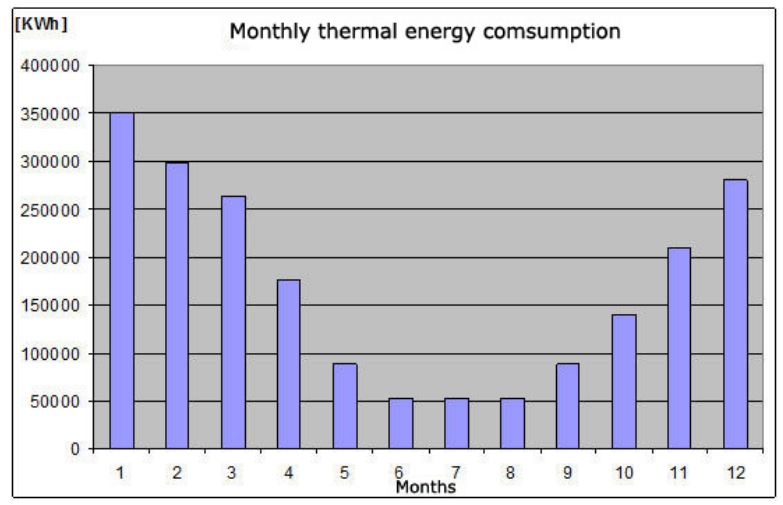

Fig. 3. Estimated monthly thermal load

B. Proposed solutions to supply the considered residential area

According to the renewable energy sources in the area, one of the following proposed scenarios to supply the consumers will be chosen by comparison with the basic solution (classic power sources). The feasibility study for all the proposed solutions is conducted for 25 years.

1) Grid connected wind farm and methane gas boiler. The wind farm is partially supplying the electrical load, the difference being purchased from the grid. The thermal energy is generated using a classic boiler with methane gas.

The optimal solution is identified using Homer. It considers 15 grid connected $26 \mathrm{~kW}$ wind turbines (PGE 
20/25). The cost for a unit is approx. 100,000 USD and the lifespan is 20 years. Replacement cost is 60,000 USD and maintenance is $100 \mathrm{USD} /$ year. Total installed power is $396 \mathrm{~kW}$. In Fig. 4 is presented the power-wind speed curve for the used wind turbine. For this case study, the monthly average speed is considered to be $5 \mathrm{~m} / \mathrm{s}$. Maximum power is generated at wind speeds of $8 \mathrm{~m} / \mathrm{s}$.

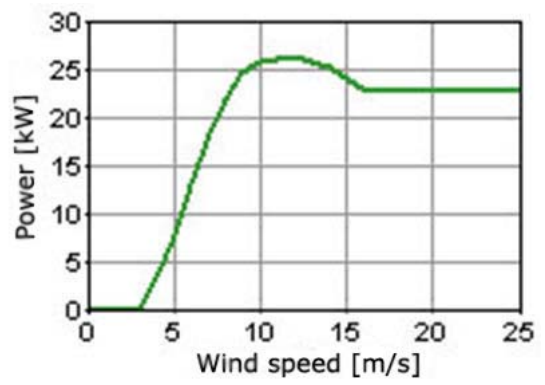

Fig. 4. Power/wind speed curve of the used wind turbine
Thermal energy is generated in a boiler of $900 \mathrm{~kW}$, which uses methane gas with $45 \mathrm{MJ} / \mathrm{m} 3$ calorific at a price of 0.35 $\mathrm{USD} / \mathrm{m} 3$. The annual generated power is 2,036 MWh.

The grid supplies the consumers when the wind farm generated power is not enough to satisfy the demand. The upper limit of power supply from the grid is $150 \mathrm{~kW}$. Every kWh is bought or sold to the grid with 0.20 USD and the price paid by the consumers for the energy delivered from the renewable sources is $0.14 \mathrm{USD} / \mathrm{kWh}$.

The selling price of the excess energy produced by the wind farm considers the cost of the green certificates. Total net cost for the entire study interval is 3,233,024 USD. In Table 1 are detailed the cost components.

Although the annual amount of consumed electrical energy is $1,405 \mathrm{MWh}, 67 \%$ is generated by the wind turbines and $33 \%$ by the grid. The wind turbines are generating 1,340 MWh, 70\% for the residential consumers and $30 \%$ is sold to the grid. The average annual generated power is $153 \mathrm{~kW}$ with an average load factor of 0.39 (which is quite small) and the number of annual operation hours is $6,411 \mathrm{~h}$.

Table I. - Cost components: grid connected wind farm and methane gas boiler

\begin{tabular}{|l|c|c|c|c|c|c|}
\hline COMPONENT & $\begin{array}{c}\text { INITIAL } \\
\text { CAPITAL } \\
{[\$]}\end{array}$ & $\begin{array}{c}\text { ANNUALIZED } \\
\text { CAPITAL } \\
{[\$ / \mathrm{yr}]}\end{array}$ & $\begin{array}{c}\text { ANNUALIZED } \\
\text { REPLACEMENT } \\
{[\$ / \mathrm{yr}]}\end{array}$ & $\begin{array}{c}\text { ANNUAL } \\
\text { O\&M } \\
{[\$ / \mathrm{yr}]}\end{array}$ & $\begin{array}{c}\text { ANNUAL } \\
\text { FUEL } \\
{[\$ / \mathrm{yr}]}\end{array}$ & $\begin{array}{c}\text { TOTAL } \\
\text { ANNUALIZED } \\
{[\$ / \mathrm{yr}]}\end{array}$ \\
\hline PGE $20 / 25$ & $1,500,000$ & 140,518 & 8,856 & 1,500 & 0 & 150,874 \\
\hline Grid & 0 & 0 & 0 & 29,141 & 0 & 90,218 \\
\hline Boiler & 0 & 0 & 0 & 32,633 & 0 & 90,218 \\
\hline Other & 0 & 0 & 0 & 63,274 & 90,218 & 32,633 \\
\hline Totals & $1,500,000$ & 140,518 & 8,856 & & 302,866 \\
\hline
\end{tabular}

Several conclusions for this scenario are presented below:

- using larger wind turbines is more economical;

- it is important to correlate the wind turbine characteristics and the parameters of the wind resource in the area;

- maximum available grid power must cover the deficit of wind turbine generated power in minimum wind conditions.

\section{2) Grid connected biogas fuel cell and methane gas boiler.}

The fuel cell generates a fraction of the load's electric and thermal power. The micro-power system considers a 200 $\mathrm{kW}$ grid connected PEM fuel cell with a limited power transfer between the system and grid at $150 \mathrm{~kW}$. The fuel cell price is 500,000 USD and the lifespan is 40,000 h (5 years). Replacement cost is 420,000 USD while maintenance is $20 \mathrm{USD} / \mathrm{h}$.

The primal energy resource is the biomass, with a price of $20 \mathrm{USD} / \mathrm{t}$ and 10 t/day availability.

The thermal load is supplied partially by the fuel cell and a $900 \mathrm{~kW}$ methane gas boiler is generating the difference. In figure 5 is presented the variation of electrical and thermal efficiency of the fuel cell as function of load value.

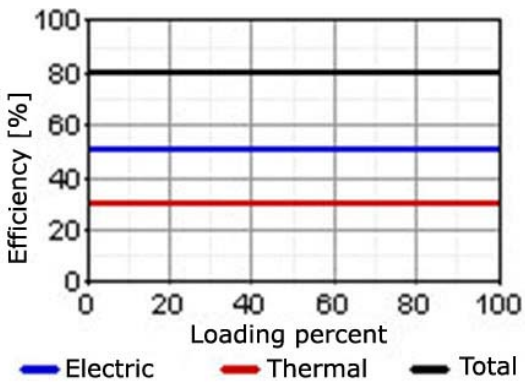

Fig. 5. Thermal and electrical efficiency curve for the fuel cell

Every kWh is bought or sold to the grid with 0.20 USD, price which includes the green certificates. The price paid by the consumers for the energy delivered from the renewable sources is $0.217 \mathrm{USD} / \mathrm{kWh}$. Total net cost for the entire study interval is 4,483,391 USD. In Table 2 are detailed the cost components.

From the annual amount of consumed electrical energy, $97 \%$ is generated by the fuel cell and $3 \%$ by the grid. The fuel cell generates 1,680 MWh: $81 \%$ for the residential consumers and $19 \%$ sold to the grid. 
Table II. - Cost components: grid connected biogas fuel cell and methane gas boiler

\begin{tabular}{|l|c|c|c|c|c|c|}
\hline COMPONENT & $\begin{array}{c}\text { INITIAL } \\
\text { CAPITAL } \\
{[\$]}\end{array}$ & $\begin{array}{c}\text { ANNUALIZED } \\
\text { CAPITAL } \\
{[\$ / \mathrm{yr}]}\end{array}$ & $\begin{array}{c}\text { ANNUALIZED } \\
\text { REPLACEMENT } \\
{[\$ / \mathrm{yr}]}\end{array}$ & $\begin{array}{c}\text { ANNUAL } \\
\text { O\&M } \\
{[\$ / \mathrm{yr}]}\end{array}$ & $\begin{array}{c}\text { ANNUAL } \\
\text { FUEL } \\
{[\$ / \mathrm{yr}]}\end{array}$ & $\begin{array}{c}\text { TOTAL } \\
\text { ANNUALIZED } \\
{[\$ / \mathrm{yr}]}\end{array}$ \\
\hline Fuel cell & 500,000 & 46,839 & 73,616 & 173,940 & 62,414 & 356,809 \\
\hline Grid & 0 & 0 & 0 & $-28,283$ & 0 & $-28,283$ \\
\hline Boiler & 0 & 0 & 0 & 0 & 49,886 & 49,886 \\
\hline Converter & 140,000 & 13,115 & 1,181 & 20,000 & 0 & 34,296 \\
\hline Other & 0 & 0 & 0 & 7,291 & 0 & 7,291 \\
\hline Totals & 640,000 & 59,954 & 74,797 & 172,948 & 112,300 & 419,999 \\
\hline
\end{tabular}

The average annual generated electric power is $193 \mathrm{~kW}$ with an average load factor of 0.965 and thermal generated power is $114 \mathrm{~kW}$. The electrical efficiency is $50.3 \%$ and the combined electric and thermal efficiency is $80.1 \%$. The average number of annual operation hours is 8,697 h. $47 \%$ of the thermal load is provided by the fuel cell, the rest being generated by the boiler.

Several conclusions for this scenario are presented below:

- the biomass price influences directly the power generation price of the fuel cell. At a price of $20 \mathrm{USD} / \mathrm{t}$ results an energy price comparable with the grid offer.

- at a price smaller than $10 \mathrm{USD} / \mathrm{t}$, the micro-power system is feasible.

- the delivery rate of the biomass must be maintained at a value imposed by the continuous operation of the fuel cell

- the maximum available power from the grid must cover the maximum power deficit of the fuel cell in conditions of its unavailability.
3) Grid connected methane gas fuel cell and methane gas boiler.

For this scenario, the fuel cell generates a fraction of both the electric and thermal load, the rest being supplied by the grid and by the boiler.

The micro-power system considers a $100 \mathrm{~kW}$ grid connected PEM fuel cell and a transfer capacity between the grid and the micro-system of $150 \mathrm{~kW}$. The lifespan of the fuel cell is $40.000 \mathrm{~h}$ (5 years).

The primary resource is methane gas with $45 \mathrm{MH} / \mathrm{m} 3$ caloric value, at a price of $0.35 \mathrm{USD} / \mathrm{m} 3$ and an unlimited availability.

To supply the thermal load, a methane gas boiler is also available.

Every kWh is bought or sold to the grid with 0.20 USD, price which includes the green certificates. The price paid by the consumers for the energy delivered from the fuel cell is $0.266 \mathrm{USD} / \mathrm{kWh}$. Total net cost for the entire study interval is 5,106,623 USD, with 250,000 USD the cost of fuel cell and 70,000 USD the DC/AC inverter. In Table 3 are detailed the cost components.

Table III. - Cost components: grid connected methane gas fuel cell and methane gas boiler

\begin{tabular}{|l|c|c|c|c|c|c|}
\hline COMPONENT & $\begin{array}{c}\text { INITIAL } \\
\text { CAPITAL } \\
{[\$]}\end{array}$ & $\begin{array}{c}\text { ANNUALIZED } \\
\text { CAPITAL } \\
{[\$ / \mathrm{yr}]}\end{array}$ & $\begin{array}{c}\text { ANNUALIZED } \\
\text { REPLACEMENT } \\
{[\$ / \mathrm{yr}]}\end{array}$ & $\begin{array}{c}\text { ANNUAL } \\
\text { O\&M } \\
{[\$ / \mathrm{yr}]}\end{array}$ & $\begin{array}{c}\text { ANNUAL } \\
\text { FUEL } \\
{[\$ / \mathrm{yr}]}\end{array}$ & $\begin{array}{c}\text { TOTAL } \\
\text { ANNUALIZED } \\
{[\$ / \mathrm{yr}]}\end{array}$ \\
\hline Fuel cell & 250,000 & 23,420 & 37,117 & 87,540 & 64,342 & 212,419 \\
\hline Grid & 0 & 0 & 0 & 111,915 & 0 & 111,915 \\
\hline Boiler & 0 & 0 & 0 & 0 & 65,689 & 65,689 \\
\hline Converter & 70,000 & 6,558 & 590 & 10,000 & 0 & 17,148 \\
\hline Other & 0 & 0 & 0 & 71,212 & 0 & 71,212 \\
\hline Totals & 320,000 & 29,977 & 37,708 & 280,667 & 130,031 & 478,382 \\
\hline
\end{tabular}

From the annual amount of consumed electrical energy, $57 \%$ is generated by the fuel cell and $43 \%$ by the grid. The fuel cell generates 875 MWh: 92\% for the residential consumers and $8 \%$ is sold to the grid. The average annual generated electric power is $100 \mathrm{~kW}$ and thermal generated power is $65 \mathrm{~kW}$. The electrical efficiency is $48.2 \%$ and the combined electric and thermal efficiency is $79.3 \%$. The average number of annual operation hours is 8,754 h. $47 \%$ of the thermal load is provided by the fuel cell, the rest being generated by the boiler.

Several conclusions for this scenario are presented below:

- the biomass price influences directly the power generation price of the fuel cell. At a price of $350 \mathrm{USD} / \mathrm{m} 3$ results a price for energy higher than the grid offer.

- the maximum available power from the grid must cover the maximum power deficit of the fuel cell in conditions of its unavailability.
4) Grid connected PV panels and methane gas boiler. The PV panels are covering partially the electrical energy consumption, the difference being purchased from the grid. The thermal load is covered by the methane gas boiler.

The micro-power system considers $400 \mathrm{~kW}$ PV panels, connected to grid and a transfer capacity between the grid and the micro-system of $150 \mathrm{~kW}$. The cost of the PV panels is 2,800,000 USD and the lifespan is 20 years. Replacement cost is 2,400,000 USD and maintenance is 240,000 USD/year.

The primal energy resource is solar energy with the parameters considered for $45^{\circ}$ north latitude and $25^{\circ}$ west longitude (Romania).

The thermal energy for the consumers is generated by the boiler from methane gas with a caloric value of $45 \mathrm{MJ} / \mathrm{m} 3$ 
at a price of $0.35 \mathrm{USD} / \mathrm{m} 3$. Total thermal energy generation is 2,036 MWh.

Every kWh is bought or sold to the grid with 0.20 USD. The price paid by the consumers for the energy delivered from the micro-power system is $0.4 \mathrm{USD} / \mathrm{kWh}$. Total net cost for the entire study interval is 3,010,000 USD, with 2,800,000 USD the cost of the PV panels and 210,000 USD the DC/AC inverter. In Table 4 are detailed the cost components.

Table IV. - Cost components: grid connected PV panels and methane gas boiler

\begin{tabular}{|l|c|c|c|c|c|c|}
\hline COMPONENT & $\begin{array}{c}\text { INITIAL } \\
\text { CAPITAL } \\
{[\$]}\end{array}$ & $\begin{array}{c}\text { ANNUALIZED } \\
\text { CAPITAL } \\
{[\$ / \mathrm{yr}]}\end{array}$ & $\begin{array}{c}\text { ANNUALIZED } \\
\text { REPLACEMENT } \\
{[\$ / \mathrm{yr}]}\end{array}$ & $\begin{array}{c}\text { ANNUAL } \\
\text { O\&M } \\
{[\$ / \mathrm{yr}]}\end{array}$ & $\begin{array}{c}\text { ANNUAL } \\
\text { FUEL } \\
{[\$ / \mathrm{yr}]}\end{array}$ & $\begin{array}{c}\text { TOTAL } \\
\text { ANNUALIZED } \\
{[\$ / \mathrm{yr}]}\end{array}$ \\
\hline Photovoltaic panels & $2,800,000$ & 262,301 & 23,615 & 40,000 & 0 & 325,915 \\
\hline Grid & 0 & 0 & 0 & 122.507 & 0 & 122,507 \\
\hline Boiler & 0 & 0 & 0 & 0 & 90,218 & 90,218 \\
\hline Converter & 210,000 & 19,673 & 1,771 & 30,000 & 0 & 51,444 \\
\hline Other & 0 & 0 & 0 & 57,255 & 0 & 57,255 \\
\hline Totals & $3,010,000$ & 281,973 & 25,386 & 249,762 & 90,218 & 647,339 \\
\hline
\end{tabular}

From the annual amount of consumed electrical energy, $45 \%$ is generated by the fuel cell and $55 \%$ by the grid. The PV panels generate 854 MWh: $75 \%$ for the residential consumers and $25 \%$ is sold to the grid. The average daily generated electric energy by the PV panels is $2,341 \mathrm{kWh} /$ day and the average number of annual operation hours is $4,387 \mathrm{~h}$. The thermal load is $100 \%$ supplied by the boiler.

Several conclusions for this scenario are presented below:

- the energy price of the PV system is double compared with the grid. The only advantage is the lack of pollution.

- the maximum available power from the grid must cover the maximum power deficit of the micro-power system in conditions of its unavailability of the solar resource.

\section{Conclusion}

This paper represents a guide for choosing the optimal energy mix of renewable sources to supply thermal and electrical energy for different consumers. This guide was used to provide the power supply solution for a tourist resort situated in Carpathians Mountains administrated by the "Politehnica" University of Timisoara. The following conclusion can be drawn:

- wind energy represents an economically feasible solution, which can ensure a lower price for energy compared to the one supplied by the grid.

- the biogas produced from the biomass can represent a feasible solution only if the daily needed quantity of biomass is assured and this quantity will generate quality biogas. The energy price can be smaller than the grid only if the biomass price is lower than $10 \mathrm{USD} / \mathrm{t}$.

- at its nowadays value, the methane gas is not a feasible solution because the price of the generated energy is bigger than the one supplied by the grid.

- in nowadays circumstances, the price of PV generated energy is much bigger compared with the one supplied by the grid and this determines that PV micro-systems are not economically feasible for supplying the residential consumers.

\section{References}

[1] HOMER V2.68 beta, National Renewable Energy Laboratory (NREL), 617 Cole Boulevard, Golden, CO 80401-3393, URL: http://www.nrel.gov/homer.

[2] http://ec.europa.eu/research/energy/pdf/estirbd_en.pdf

[3] Gh. Vuc, I. Borlea, C-tin. Barbulescu, O. Prostean, D. Jigoria-Oprea and L. Neaga, "Optimal Energy Mix for a Grid Connected Hybrid Wind - Photovoltaic Generation System", in 3rd IEEE International Symposium on Exploitation of Renewable Energy Sources - EXPRES 2011, March 11-12, Subotica, Serbia, pp. 1-6, 2011.

[4] Y. P. Verma et. al., "Profit maximization and optimal sizing of renewable energy sources in a hybrid system", in International Journal of Engineering Science and Technology, Vol. 2(9), 4575-4584, 2010.

[5] O. Ekren and B.Y. Ekren, "Size optimization of a PV/wind hybrid energy conversion system with battery storage using response surface methodology”, in Applied Energy, 85, 1086-1101, 2008.

[6] P. Nema, R.K. Nema and S. Rangnekar, "A current and future state of art development of hybrid energy system using wind and PV-solar: A review", in Renewable and Sustainable Energy Reviews, 13, 2096-2103, 2010.

[7] J. Paska, P. Biczel and M. K1os, "Hybrid power systems An effective way of utilizing primary energy sources", in Renewable Energy, 34, 2414-2421, 2009.

[8] A. Souissi, O. Hasnaoui and A. Sallami, "Optimal Sizing of a Hybrid System of Renewable Energy for a Reliable Load Supply without Interruption”, European Journal of Scientific Research, ISSN 1450-216X Vol.45 No.4 (2010), pp.620-629, 2010.

[9] D. SahebKoussa and M. Belhamel, “Contribution à l'étude théorique du comportement d'un système hybride (éolienphotovoltaïque-diesel) de production d'électricité sans interruption”, dans Revue des Energies Renouvelables 11, pp. 137-151, 2008.

[10] H. Yang, W. Zhou, L. Lu and Z. Fang, “Optimal sizing method for stand-alone hybrid solar-wind system with LPSP technology by using genetic algorithm”, in Solar Energy 82, pp. 354-367, 2008. 